\title{
Implementation of Selected Assumptions of Participatory Management in Creating Safety and Security Promotion in the Polish School
}

\author{
Ewelina WŁODARCZYK \\ Pedagogical University in Cracow, Cracow, Poland \\ ewelina.wlodarczyk@up.krakow.pl
}

Received date: 20 February 2019; Accepted date:30 April 2019; Published date: 4 July 2019

Academic Editor: Dorin Maier

Copyright (C) 2019. Ewelina WŁODARCZYK. Distributed under Creative Commons CC-BY 4.0

\begin{abstract}
Safety and security promotion have been implemented in Polish schools for several decades. However, the effectiveness of these measures raises doubts when analyzing the scale of risky behaviors among children, young people and adults. Statistical analyses conducted by the Police suggest that there is still a lot to do with regard to safety assurance. It was actually those data, along with an analysis of the school programmes of education and prevention that became the motivation to embark on extended research concerning these issues. Owing to the studies conducted in 2018 and 2019, it became possible to obtain the answer to the question: To what extent are the selected assumptions of participatory management considered in the school safety and security promotion? Participation in the educational and preventive programmes in schools was virtually unnoticeable. For this reason, it proved necessary to carry out surveys among teachers and school leavers in order to enable a diagnosis to be made concerning the way of understanding the essence of safety assurance, the scope of the actual participation of pupils in the preventive actions and the evaluation of these actions by teachers and school leavers. An analysis of the data obtained made it possible to formulate recommendations to enable a more comprehensive preparation of teachers and teacher candidates for initiating preventive actions. As it turned out, it was particularly important to include the holistic understanding of safety assurance in curricula for teacher candidates. Elimination of risk factors, which teachers focus on, is equally important as strengthening the factors that protect against risks. Of key importance in this respect is the need for understanding the essence of safety in both positive and negative dimensions. Such an approach, taking account of highquality methodology of classes, is necessary in implementing high-quality safety and security promotion in schools.
\end{abstract}

Keywords: education for safety, safety and security promotion, safety participatory management

Cite this Article as: Ewelina WŁODARCZYK (2019)," Implementation of Selected Assumptions of Participatory Management in Creating Safety and Security Promotion in the Polish School ", Journal of eLearning and Higher Education, Vol. 2019 (2019), Article ID 531037, DOI: 10.5171/2019.531037 


\section{Introduction}

School plays a key role in shaping the competences necessary for all young people to counteract threats and seek personal development. That is why it is worth analyzing the management methods applied in order to provide high quality promotion. Motivation to implement activities in an effective manner that enhances shaping the safety and security environment may not only concern providing information about threats. According to the goal setting theory by E.A. Locke, personal commitment is connected with internalising the goal and perceiving it in the category of an own initiative. It is possible when we implement the assumptions of participation and will formulate goals (Locke, 1996) concerning shaping the safety and security environment at school together with the group. Proper management which is perceived more in the category of leadership and the awareness that the goal is attainable (Locke, 1996) are of crucial importance. Low effectiveness of the command and control system and a high level of control in relation to trust and freedom to decide how to implement the adopted tasks should be highlighted (Ćwik, 2005). One of the assurance strategies is education for safety. Its effectiveness is, however, determined by the methodological competences of the educators. The classes must not be reduced to lectures and talks; and the sources of the fullest information on the ways of providing effective safety and security promotion are teachers and pupils.

Effective safety and security promotion require participation. Due to the fact that counteracting threats and strengthening protective factors, which belong to extremely important areas in prevention, are not always implemented in practice, teachers and students should get involved in them.

The meaning of this issue is related to several aspects. First of all, the incomplete understanding of the concept of safety and security promotion may determine the type of activities undertaken in this area.
Secondly, reducing prevention to counteracting threats significantly simplifies the issue and skips its key dimensions. Thirdly, schools do not always offer room for participation. Thanks to the analysis of school documentation, it is possible to suppose that students very rarely participate in safety and security promotion at school. Finally, the assessments formulated by students and teachers regarding prevention are important. Failure to cooperate may lead to discrepancies in the assessment of the undertaken activities and then, it is difficult to design effective safety and security promotion.

\section{Literature Review}

The source literature dedicates little space to the participation in safety and security promotion at school. While reviewing the literature, I analyzed both the research on the participation, and safety and security promotion.

With regard to the issue in question, the way of understanding the following terms: "safety and security" and "promotion" is of particular importance. Safety and security should not be identified only with the absence of threats, but with a continuous process, which consists of a series of constantly undertaken actions which are aimed at improving the condition and sense of human safety and security (Zięba, 2012; Korzeniowski, 2017; Ćwik, 2018; Świerszcz, 2017; Świerszcz, 2019, Świerszcz, 2016). A holistic approach to school safety and security promotion requires taking account of the internal and external aspects of "safety and security" and its positive and negative dimensions, focusing on eliminating threats on the one hand, and on the other hand - on preparing people to deal with challenges of the modern world. Understanding safety and security as an objective state, and at the same time a state that is subject to subjective assessments is crucial as well (Frei, 1977; Nowak, 2015; Zięba, 2012; Korzeniowski, 2017; Pieczywok, 2012; Nye, 1989, Brauch, 2011; Grenda, 2017). This conviction is a pillar to

Ewelina WŁODARCZYK (2019), Journal of e-Learning and Higher Education, DOI: $10.5171 / 2019.531037$ 
understand the need to diagnose threats in a comprehensive manner before launching preventive activities related to them. However, one should be aware that people will not always inform their supervisors about threats (Ćwik, 2017). Therefore, what is absent is the social awareness, which may be related to a low safety and security culture (Cieślarczyk, 2011).

As it is commonly understood, safety and security promotion is reduced to preventing risky behaviours. Due to the fact that at present it is impossible to prepare humans to deal with threats and emergency situations, promotion actions should be considered in a holistic way, distinguishing two dimensions indicated by R. Zięba, namely; a positive and negative dimension (Włodarczyk, 2018b). Such a typology is consistent with the classification established by Z.Gaś and S. Śliwa, who described positive (creative, offensive) promotion (prevention) focused on developing factors protecting people from threats, e.g. social ties, hobbies and interests, self-esteem, empathy (Schonert-Reichl, 2012; Santos, 2011), communication skills and negative (defensive) promotion (prevention), aimed at eliminating risk factors, i.e. disorders, dysfunctions and threats (Gaś, 2006; Śliwa, 2015; Hundeloh, 2003).

Participatory management is an approach which became popular in the 70's and 80's of the $2^{\text {th }}$ century (Dachler, 1978; Cotton, 1988; Wagner, 1987; Locke, 1979). The importance of participation in the research in the $80^{\prime}$ 's and $90^{\prime}$ s of the 20 th century was dedicated to occupational health and safety management (Clarke, 1982; Glendon, 1982; Rest, 1996). As studies show, participation while making decisions makes it possible to achieve greater satisfaction from the work (van Mierlo, 2005; Kim, 2002), satisfaction and well-being (Rasmussen, 2006; van Mierlo, 2005; Nielsen, 2012; Parnell, 2003; Kim, 2002), involvement (Rasmussen, 2006; Kumar, 2017), co-responsibility and mutual support while performing the tasks (van Mierlo, 2005), greater efficiency (Hargreaves,
1991; Likert, 1967 in: Shagholi, 2011), the sense of belonging to the organization and motivation to achieve better results (Kumar, 2017). Employees who do not participate in decision-making processes may not have the feeling of sharing responsibility or get fully involved in implementing them (Nielsen, 2012). It shows how important coresponsibility is in safety and security management. The research indicates greater efficiency of safety participatory management in comparison with unilateral actions (Gunningham, 2008; Soehod, 2008; Clarke, 2006; Luria, 2012).

Safety participatory management is a system of "activities of all entities located in the institution and its neighbourhood, the common goal of which is to build an environment and a safety and security culture" (Włodarczyk, 2018a). Safety and security promotion which takes account of the assumptions of participatory management will mainly aim to: make teachers and students involved in formulating common objectives of action and consider the needs, offers, ideas and feedback from all members of the school community as far as implementation of preventive activities is concerned. Thanks to the references to the idea of social participation, the goal of each entity might become the goal of the team and thus, the motivation to achieve it is greater.

School documents that regulate safety and security promotion activities include: school statutes, school preventive maintenance program and a set of curricula. However, effective safety and security management requires understanding its essence, the ability to diagnose the causes and reasons of threats, preparing students and teachers to respond to the challenges and threats of the modern world, noticing the necessary changes and participation at every stage of preventive measures that can increase the motivation to take their own initiatives that promote safety and security (Włodarczyk, 2017). 


\section{Problem statement}

The analysis of school preventive maintenance programs leads to the conclusion that participation of students in preventive activities is incidental in nature. Hence, there is a need to conduct an in-depth diagnosis in this respect, which was possible thanks to the research conducted in 2018 and 2019.

The main research problem was formulated in the form of the following question: To what extent are the selected assumptions of participatory management considered in the school safety and security promotion? As part of the problem formulated in such a way, specific problems were identified:

- How do teachers and headmasters understand the essence of safety and security?

- To what extent do schools take account of the need to eliminate risk factors and strengthen factors that protect from risks in the safety and security promotion?

- What is the scope of students' participation in activities for the safety and security promotion?

- How do students and teachers assess the effectiveness of school safety and security promotion?

Thanks to the conducted research, it was possible to answer the above questions. The analysis of the obtained data made it possible to formulate conclusions that may contribute to more thorough considerations of the assumptions of participatory management by teachers and headmasters and, consequently, to designing more effective promotion/prevention measures.

\section{Methods}

The research was done using a diagnostic survey conducted in a group of 140 teachers of all educational stages and 113 school graduates (first-year students). An electronic questionnaire was applied for the research, which had been sent to teachers via social networking platforms and to students of one of the universities in Cracow. Intentional selection was applied in order to select graduates and teachers of primary and secondary schools which was dictated by the desire to obtain the opinions of those respondents who were interested in cooperating while designing effective safety and security promotion.

The method of analyzing documents, including the available literature and normative acts the school operation is based on, and the school documentation (e.g. school preventive programmes) was also of key importance while formulating research indicators. The choice of the educational and preventive programmes that were subjected to the analysis was determined by the respondents' indications in the questionnaires where they indicated which school they completed and what sort of shortages they noticed concerning safety assurance in this particular school.

The choice of the diagnostic survey method resulted from the possibility to obtain a lot of data anonymously. Thanks to the electronic survey questionnaire, it was possible to reach many teachers all over Poland. The analysis of the documents, on the basis of which schools conduct preventive activities in the area of safety and security was also crucial. It made it possible to learn about formal requirements set for schools and to verify the answers given by teachers and school graduates.

\section{Results}

\section{Understanding the essence of safety assurance}

The studies have shown that the incomplete understanding of the term "safety and security" is very problematic for teachers. It is very difficult to manage and promote

Ewelina WŁODARCZYK (2019), Journal of e-Learning and Higher Education, 
safety and security effectively without being familiar with the proper interpretation of the essence of the term. The majority of the studied teachers and headmasters could provide the definition of safety and security, although $64 \%$ of them defined safety and security in a one-dimensional manner and pointed only to its negative aspect regarding preventing threats. It confirms the research conducted in 2017 (Włodarczyk, 2017). Only $11 \%$ of all respondents (Fig. No. 1) perceive safety and security in a holistic and multidimensional manner, and recognize the need to counteract threats on the one hand and to support human development on the other hand. For those teachers, safety and security is: "an environment in which no one is afraid or distracted, everyone can learn, be creative, can direct all potential to manage development", "Absence of threat, good conditions for development and learning",
"Optimal conditions for children's development", "The feeling of peace and stability", "Peace, good atmosphere favouring development...", "Ensuring development, opportunity to learn and live without a life risk". None of the surveyed teachers took account in the definition of the need to develop the competencies necessary to respond to the challenges of the modern world in a flexible manner, although out of $24 \%$ of the respondents who noticed the positive aspect of safety and security, two teachers signaled the need to develop factors protecting from threats, i.e. creativity, personal development, acceptance and tolerance. However, there were no factors crucial for positive promotion/prevention in the provided answers, such as developing social ties, students' hobbies and interests, empathy, high self-esteem, assertiveness, social communication or team work.

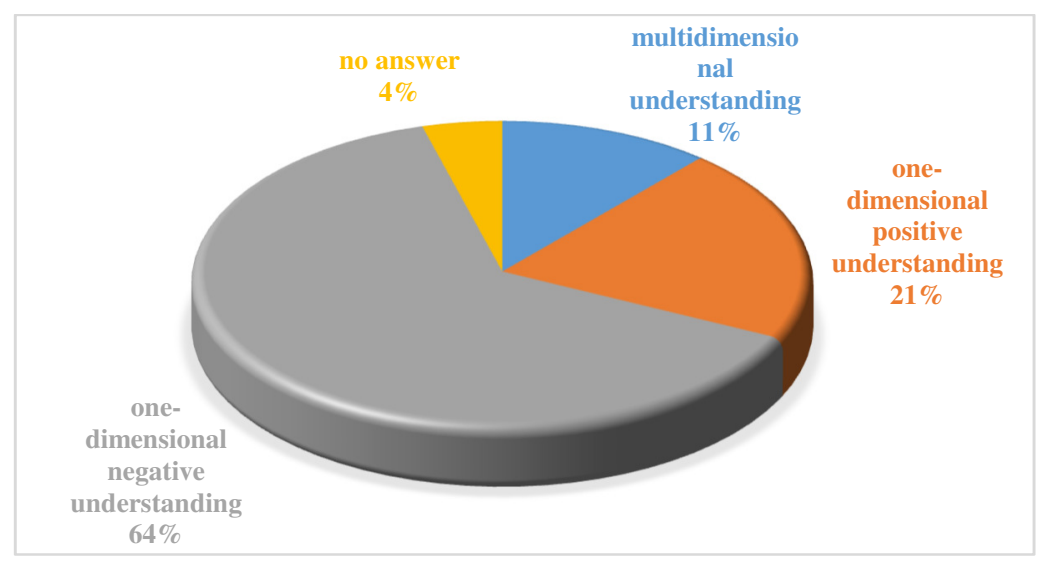

Fig. 1: Defining the concept of "safety and security" by the surveyed teachers

The most characteristic definitions, which result in the negative perception of safety and security by the surveyed teachers include: "Safety and security = minimizing threats", "The fact that there is no risk at school for students and teachers", "Awareness of threats and the ability to counteract them", "It's the absence of threats", "All activities of occupational safety and health", "Safety means a feeling of no threat", "Protection against threats", "This is a condition which does not threaten our health and life, it is avoiding everything that can hurt us - expose us to some psychological, physical, etc. threats", "No threat to mental, physical and life health", "Providing conditions that do not pose a risk", "Minimizing risk", "Staying in conditions that do not threaten my life and health", "The situation in which there are no threats", "No accidents". It should be noted that most of

Ewelina WŁODARCZYK (2019), Journal of e-Learning and Higher Education, 
these definitions apply only to the external aspect of safety and security, i.e. creating situations in which no one will threaten or pose a risk to the person in question. The analysis of the percentage of responses provided by the teachers of various subjects provided additional conclusions.

Table 1: Defining the concept of "safety and security" by the surveyed

teachers of various subjects

\begin{tabular}{|l|c|l|l|l|}
\hline & Multidimensiona & $\begin{array}{l}\text { One- } \\
\text { dimensional } \\
\text { negative } \\
\text { understandin } \\
\text { g }\end{array}$ & $\begin{array}{l}\text { One- } \\
\text { dimensional } \\
\text { positive } \\
\text { understandin } \\
\text { g }\end{array}$ & $\begin{array}{l}\text { No } \\
\text { answe } \\
\text { r }\end{array}$ \\
\hline Teachers of scientific subjects & 6 & 59 & 24 & 12 \\
\hline Teachers of humanities & 19 & 60 & 19 & 2 \\
\hline $\begin{array}{l}\text { Teachers of natural science } \\
\text { subjects }\end{array}$ & 11 & 56 & 22 & 11 \\
\hline Teachers of social subjects & 4 & 74 & 13 & 9 \\
\hline Early school education & 6 & 59 & 35 & 0 \\
\hline $\begin{array}{l}\text { Pedagogues/psychologists/speec } \\
\text { h therapists/library teachers, et } \\
\text { al. }\end{array}$ & 21 & & & \\
\hline Teachers of vocational subjects & 17 & 50 & 33 & 0 \\
\hline Preschool education & 0 & 75 & 25 & 0 \\
\hline $\begin{array}{l}\text { Teachers working in the common } \\
\text { room for children }\end{array}$ & 0 & 100 & 0 & 0 \\
\hline
\end{tabular}

The main reason for the incomplete understanding of "safety and security" may be connected with the Polish system of preparing teachers for the profession. In the regulation which establishes educational standards for candidates for teachers, little space is dedicated to safety and security. In the current legal situation, this problem has been only indicated as contents and materials regarding occupational health and safety, and safety and security at school, without indicating the number of hours needed for their implementation. Noteworthy is the fact that among the surveyed groups of teachers, the greatest percentage of respondents understanding the multidimensionality of "safety and security" was the least numerous group of pedagogues, psychologists, speech therapists, library teachers and others (support teachers, special pedagogues). A holistic approach to safety and security was also observed among: teachers of humanities (the largest group), vocational subjects, and - to a lesser extent - natural science subjects. Teachers of social subjects (e.g. PE, social studies, education for safety and security, education of family life), along with kindergarten teachers, constituted a group in which the highest percentage of respondents observed only the negative aspect of safety and security. Teachers of some subjects, such as PE, chemistry or some vocational subjects, must particulary focus on safety and security of children and teenagers in the negative dimension of this concept, which to some

Ewelina WŁODARCZYK (2019), Journal of e-Learning and Higher Education, 
extent justifies the answers they provided. The specificity of preparing pedagogues and psychologists to their profession is related to diagnosing the grounds for risky behaviors to a greater extent. That approach may translate into understanding the essence of promotion/prevention in a better way.

The answers provided by the teachers to the question concerning the implementation of classes on school safety and security during their studies might justify the abovementioned conclusions. Over a half of the respondents declared that they had taken part in such classes even though completed teacher training should ensure that everyone is prepared in this field. The most frequently selected forms of development and improvement include conferences and trainings which are mostly organized as part of intra-school vocational training, and teachers are obliged to participate in them.

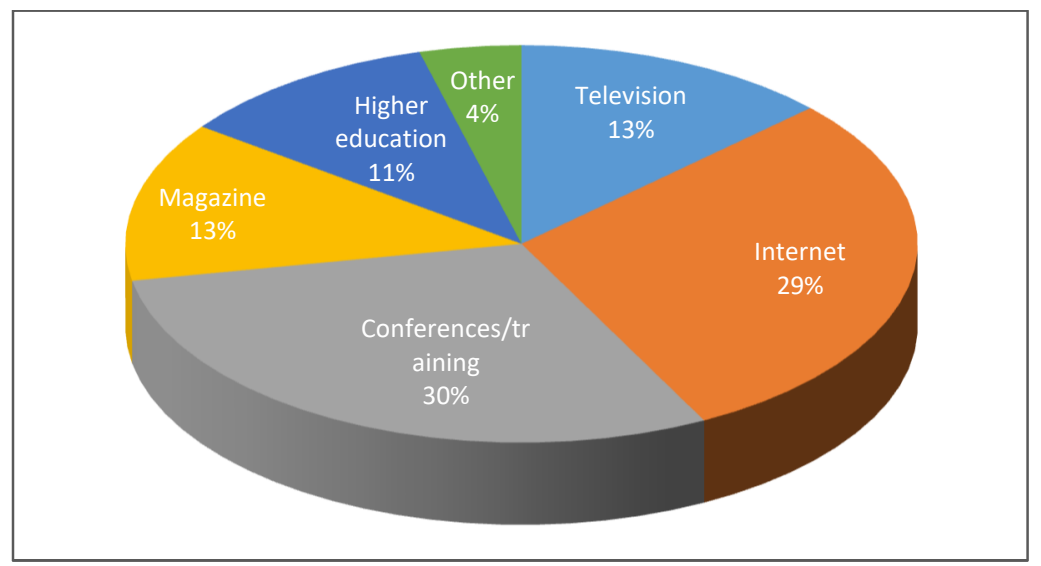

Fig. 2: The sources of teachers' knowledge about safety and security

While analyzing the sources from which teachers learn about threats at school, one might arrive at interesting conclusions. It illustrates the importance of students' participation. The largest number of respondents notice risks at school which are associated with verbal aggression (68\% of the respondents), Internet addiction (65\%), physical aggression (47\%) and smoking (37\%). Violence was indicated by only $25 \%$ of the teachers, vandalism by $14 \%$ of the respondents, alcohol consumption by only $6 \%$, and drug use by $5 \%$ of the teachers included in the survey. Certainly, one should be aware that this is disclosed data, and teachers do not always manage to diagnose each student properly. From the point of view of the surveyed school graduates (over $70 \%$ ), smoking was the biggest problem at school, followed by alcohol consumption
(29\% of the respondents), Internet addiction and poor condition of rooms and school buildings (25\%). Only $22 \%$ of the surveyed school graduates indicated verbal aggression and vandalism. It turns out that teachers do not always diagnose threats adequately that are important for students, but it is difficult to reach a proper diagnosis when only $22 \%$ of them learn about threats while talking to students. Unfortunately, according to the teachers participating in the survey, the basic source of knowledge about risks at school is conferences and trainings. Out of $38 \%$ of the surveyed teachers who mentioned this form of obtaining knowledge about threats, nearly a third indicated that those were obligatory trainings provided by the board of teachers. It confirms the conclusions formulated in the previous question. 


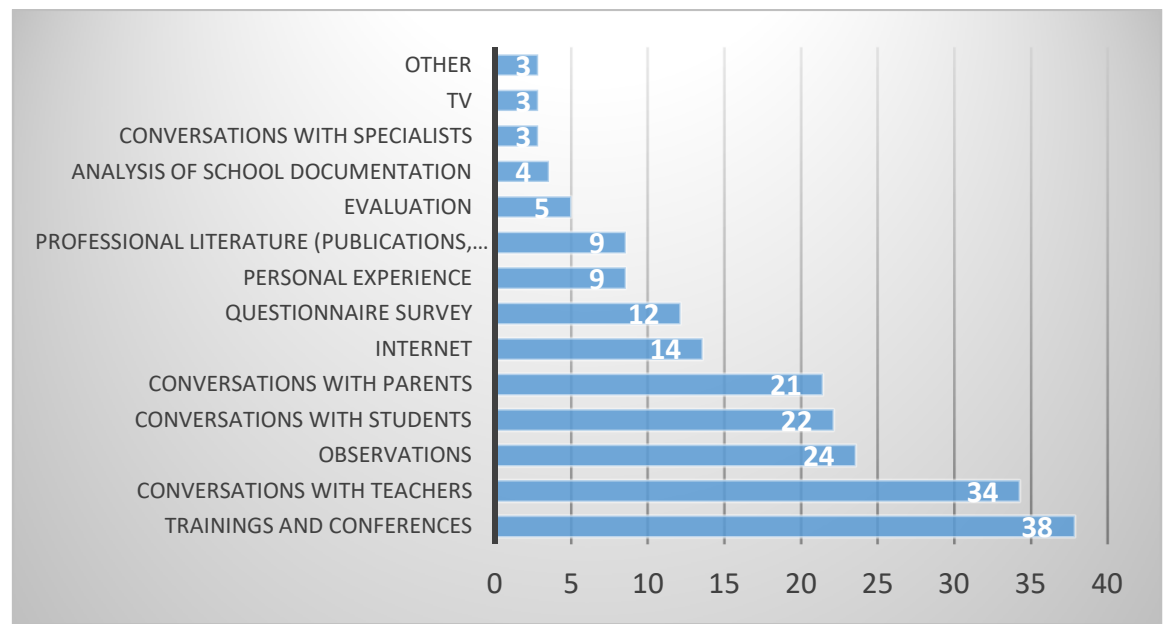

Fig. 3: The sources of teachers' knowledge about threats at school

A lot of information about threats at school stems directly from conversations with other teachers. This form of exchanging views and opinions is valuable as it makes it possible to look at the problem in an objective way, devoid of personal prejudice. Observing situations at school and leading conversations with students and parents also provide valuable insights. Due to the extensive curriculum that every teacher is obliged to fulfill, teachers sometimes run out of time to have such conversations. Unfortunately, the evaluation was indicated by only $5 \%$ of the respondents. This is a key element of the quality of safety and security promotion which takes account of the assumptions of participatory management. All school documents, in particular school preventive maintenance program, school statutes, curricula and safety and security procedures in the facility should be subject to evaluation.

Valuable information is provided by the analysis of activities which - according to teachers - should be implemented so that school is a safer place. The question was not obligatory, and only $57 \%$ of the respondents answered it, $10 \%$ of whom stated that their school is a safe place. $19 \%$ of them notice the necessity to introduce a number of control mechanisms, i.e. access control, introduction of safety and security procedures, a ban on leaving the building during breaks or security guards. With no doubt these solutions contribute to solving the problem of eliminating risk factors, but do not strengthen factors that protect against threats. Further suggestions included: increasing the scope of teachers' duty hours (9\%), expanding/installing the CCTV systems (9\%), disciplinary actions for students breaking the rules (6\%). The need to improve students' social competences and promote tolerance, which is included in the rhetoric of positive promotion/prevention, was indicated by only $3 \%$ of the surveyed teachers, and the need to establish common safety and security principles acting as a pillar of participation in school safety and security management was observed by only $1 \%$ of the teachers. These ideas are justified when we analyze the responses provided by the school graduates. Over a fifth of them did not notice any activities undertaken by their schools which would focus on promoting safety and security. 


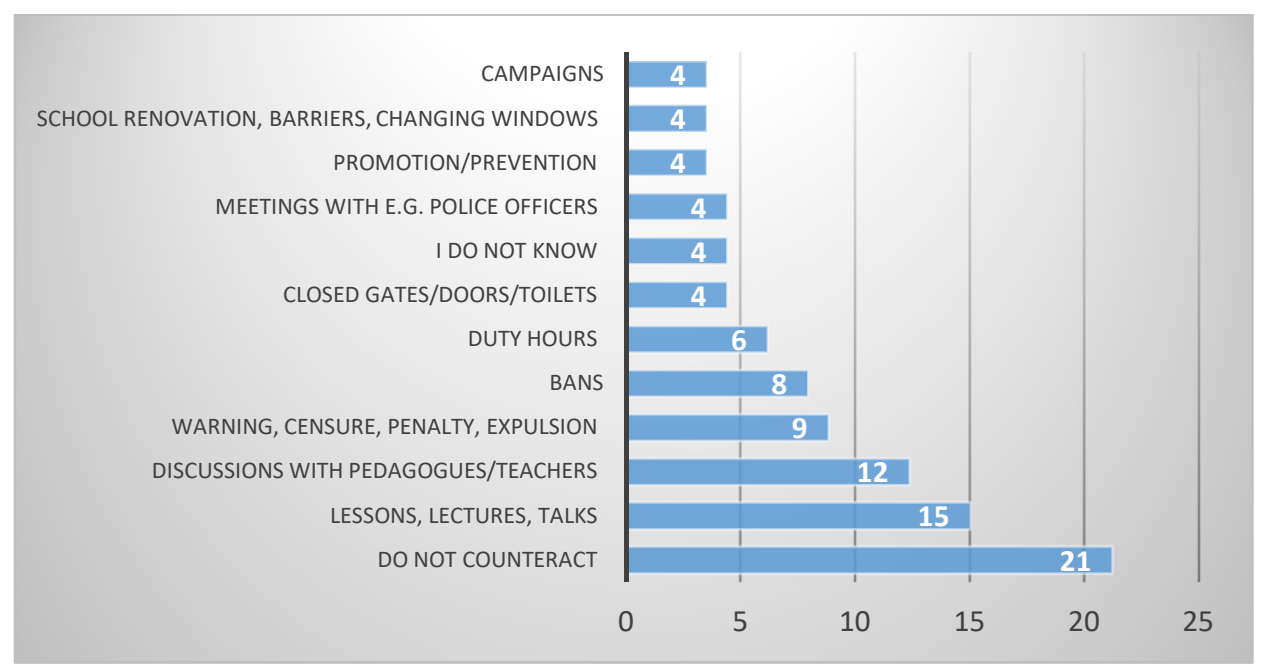

Fig. 4: Safety and security promotion actions undertaken by schools - from the point of view of the school graduates

Among the visible actions undertaken by schools, the school graduates indicated providing information about threats (e.g. during lessons or lectures), discussions with teachers/pedagogues as well as a wide range of penalties, bans and controls. The system of orders and prohibitions does not fit into the positive promotion/prevention, and providing information, due to its one-way information flow, and it does not exhaust the characteristics of safety participatory management. The effectiveness of such activities is low. Excessive concentration on risk factors and eliminating threats leads to the conviction that a comprehensive approach to safety and security which involves reacting to the challenges of the modern world in a creative manner is not a common practice at Polish school. The answers provided by the teachers to the question concerning introducing a ban on the use of mobile phones at school, the existence of which was confirmed by $60 \%$ of the surveyed teachers, confirms the above thesis. Modern technologies belong currently to one of key challenges of the $21^{\text {st }}$ century. If those technologies are supposed to trigger and enhance human development, they must be applied in a smart way - otherwise, they can be a source of many threats. Such competences should be obtained by students at school, but the introduction of statutory prohibitions on the use of mobile phones does not favor achieving this goal. In this case, the safety and security management at school does not fit into the assumption of social participation and reduces at the same time the effectiveness of the implemented safety and security promotion. Surveillance, which is omnipresent in schools, has similar effectiveness. Over $80 \%$ of the school leavers in the survey declare that this method of eliminating risky behaviors in their schools was used. Surveillance plays a key role in tracking down the perpetrators or establishing the course of the incident when a hazardous situation occurs. It does not, however, develop those characteristics among the pupils that should be the priority in education, i.e. the internal need for functioning based on universal human

Ewelina WŁODARCZYK (2019), Journal of e-Learning and Higher Education, 
values. E. Fromm defined them as humanistic conscience (Fromm, E. 2011).

A crucial role in preparing teacher candidates for delivering effective safety and security promotion is played by the system of higher education. Only half of the teachers $(51.4 \%)$, however, declared that issues concerning safety at school were included in their curricula. This percentage may suggest a low level of understanding of the essence of safety assurance among the teachers in the survey. The lack of understanding of the assumptions of safety and security promotion among teachers and headmasters is corroborated by an analysis of educational and preventive programmes in selected schools. One of the schools included a large number of objectives consistent with the idea of strengthening the factors that protect against risks, e.g. developing empathy, collaboration, involvement and willingness to acquire knowledge. The school even made a diagnosis of the problems occurring among young people, e.g. wrong relations with the family, lack of self-acceptance or substance abuse. The programme specifies and defines factors that protect against risks but does not include the priorities of safety assurance that were indicated by the young people. Instead, the school focuses on developing selfgovernance and restrains building selfesteem by reducing it to merely a few weekly class meetings concerning the topic, 'What does it mean to be a valuable man?' or 'Building your own self-esteem', without indicating any concrete actions related to these matters. In the programme, the school emphasizes the need for shaping the ability to use the media in a conscious manner. And here, there appear some suggestions, e.g. to develop 'a list of risks related to thoughtless use of the media' instead of preparing pupils for informed rational use of the mass media. Also, of little importance is the 'developing a register of impermissible attitudes' suggested in the programme instead of focusing on the socially accepted attitudes. Then, the school associates respect for other people's work with, inter alia, 'the class monitor's responsibility for enduring order in the classroom after the lesson'. Such examples could be multiplied, and their effectiveness is low because they do not rely on developing positive attitudes but on eliminating the negative behaviors.

\section{The scope of pupils' participation in preventives actions}

The teachers were also asked about the scope of students' participation in actions related to safety and security promotion at school. The examples of initiatives mentioned by the surveyed teachers are to a small extent covered by the assumptions of participatory management. 


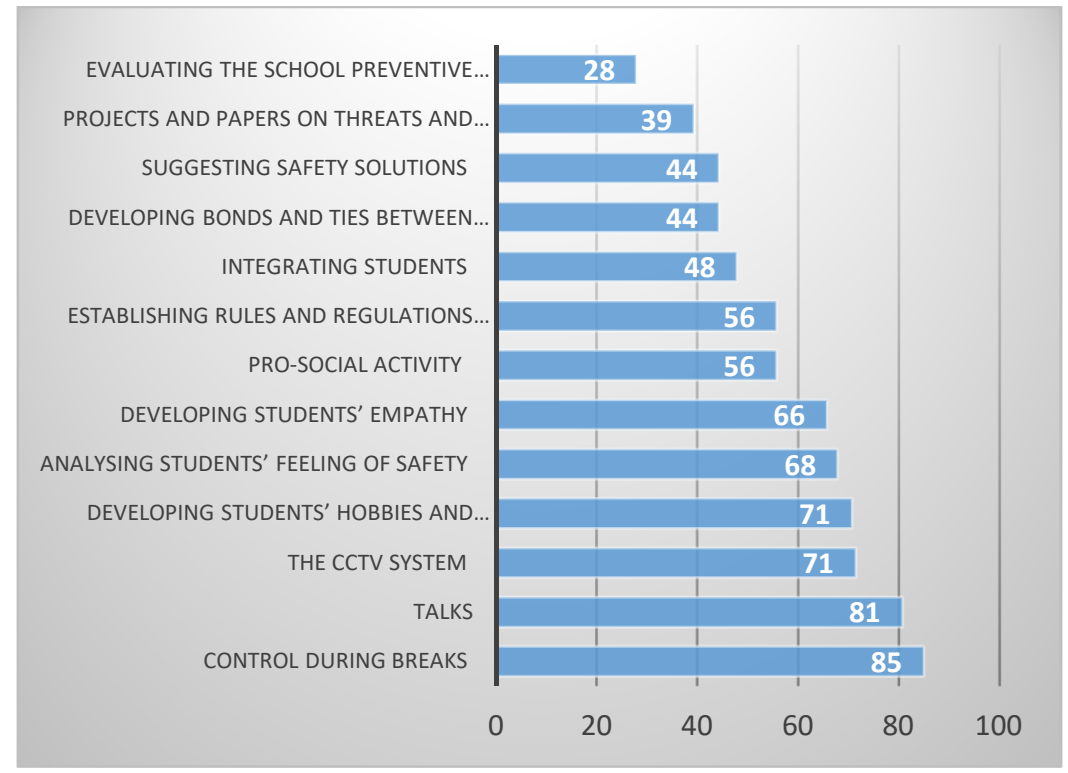

Fig. 5: The scope of students' participation in preventive actions - from the point of view of the teachers

The control, which was indicated by the largest percentage of the teachers participating in the survey is unilateral and the scope of students' participation in this process generally does not exist. A similar situation might be observed in the case of talks with the specificity of which is related to leading the conversation in such a way so that the obtained conclusions are identical with the views of the teacher. The CCTV system belongs to those solutions which reduce the role of school exclusively to supervision. However, over $70 \%$ of the surveyed teachers observed the need to develop students' hobbies and interests and to analyze their feelings of safety. These activities are a form of participation in the safety and security promotion. What is more, developing young people's interests, their empathy and making them involved and engaged in pro-social activities belong to some of the most important factors protecting from risks that fit into the rhetoric of positive promotion/prevention. Similar answers were also provided by the school graduates. They noticed that school was concerned about their hobbies and interests - the score given by $55 \%$ of them was 4 out of 5. As far as making students engaged in pro-social activities, the graduates were more critical and in $46 \%$ of cases the score of the proposed forms of activity in this area was 3. Over a half of the surveyed teachers also made their students involved in constructing and establishing school and class regulations, which demonstrates implementing high-level safety and security promotion at school by those groups. Taking account of individual ideas suggested by students and including them in the regulations encourages greater motivation for their subsequent implementation. Enabling students to formulate suggestions and solutions concerning safety and security is of similar importance, but such actions were declared by only $44 \%$ of the surveyed teachers. More attention should be paid to evaluating preventive activities, as only $28 \%$ of the respondents allow students to assess school preventive maintenance programs.

Ewelina WŁODARCZYK (2019), Journal of e-Learning and Higher Education, 
Others make participation in this area impossible and resign from introducing modifications that increase the effectiveness of these programs in the future. Therefore, participation might be observed in offers and proposals, but the teachers refrain from evaluating the undertaken actions which is evidenced by the answers given by the school graduates, which in some aspects were close to the declarations provided by the teachers.

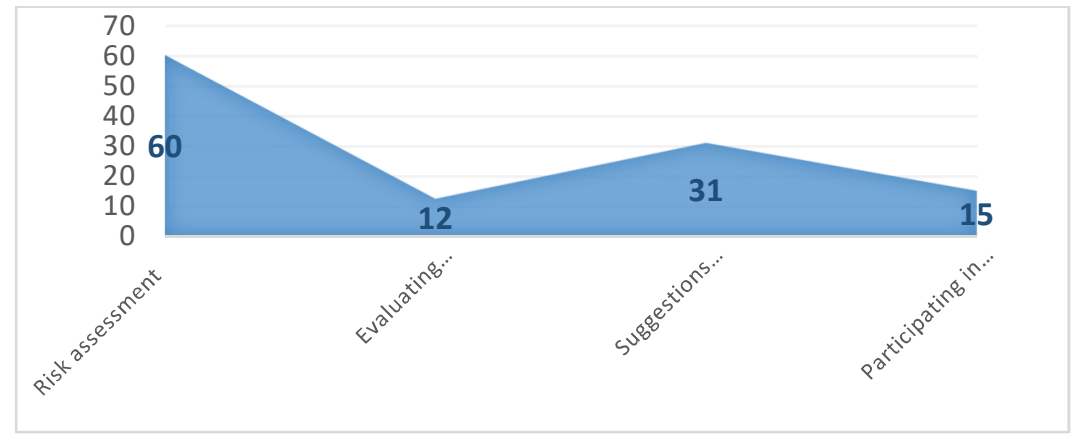

Fig. 6: The scope of students' participation in preventive actions - from the point of view of the school graduates

The only significant difference between the teachers and the school graduates was related to assessing school preventive maintenance programs. Almost a third of the surveyed teachers declared that school undertakes such activities. The same was confirmed by only $12 \%$ of the school graduates. This fact indicates that students do not feel so involved in the school safety and security promotion as it was assessed by the surveyed teachers.
Evaluation of the effectiveness of safety assurance implemented in the school

Slight discrepancies between the teachers and the students are also observed in opinions on the effectiveness of safety and security promotion at school. In comparison to the school graduates, the teachers evaluated the preventive actions undertaken by the institution significantly higher.

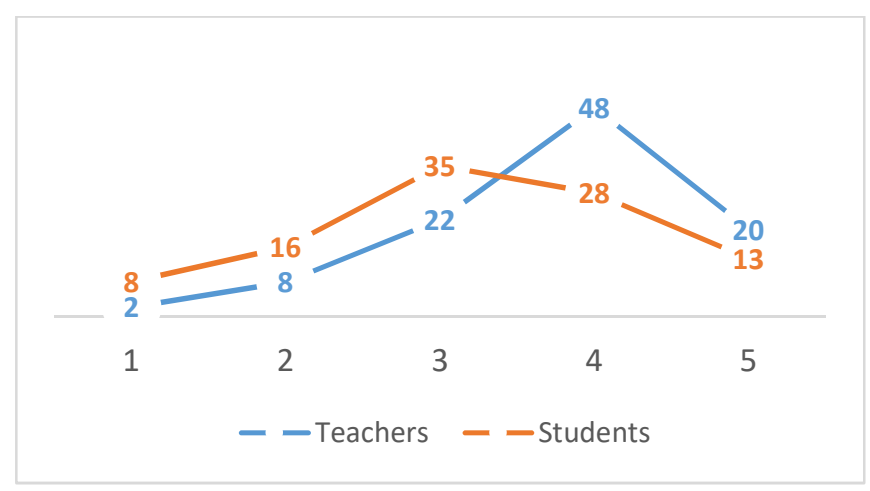

Fig. 7: The comparison of assessing the effectiveness of preventive actions regarding safety and security

Ewelina WŁODARCZYK (2019), Journal of e-Learning and Higher Education, DOI: $10.5171 / 2019.531037$ 
While evaluating the effectiveness of safety and security promotion at school, the respondents used a scale in which 1 equaled" unsatisfactory", whereas 5" very good". The school graduates more often assessed the effectiveness of promotion as 3 , while for the majority of teacher's promotion was evaluated at the level of 4 . However, safety and security promotion were evaluated as 4 and 5 by $68 \%$ of the teachers, while in the group of the school graduates, similar grades were recorded by only $41 \%$ of the respondents. Therefore, there is a visible area of changes that should be introduced, as a relatively small percentage in both research groups used the highest possible assessment (very good) to evaluate the effectiveness of safety and security promotion. Noteworthy is the fact that despite such evaluations, only $57 \%$ of the surveyed teachers decided to suggest measures aimed at improving safety and security at school. Lower grades given by the school graduates may be associated with maladjustment of safety and security promotion to the needs of students, failure to take account of their suggestions and depriving them of the possibility to decide on actions the consequences which regard them.

A manifestation of the understanding of the essence of safety and security by the teachers is to include the design activities that provide safety and security, and factors that protect people from threats. Among them, empathy plays a key role. Many of the surveyed teachers, when asked about activities aimed at enhancing empathy of students undertaken last month, indicated talks (19\%) and conversations $(18 \%)$. Only $11 \%$ of the respondents pointed to practical activities, i.e. volunteering, pro-social and charitable activities, and only $6 \%$ of the teachers selected a very effective method - namely $a$ case study, i.e. analyzing individual cases of the sick and people in need. Answers suggesting a real understanding of the role of empathy in developing a culture of safety and security at school were provided occasionally:" Meetings for students to raise awareness about difficulties experienced by a child suffering from Asperger syndrome, highlighting his/her strengths and a talk about methods to deal with difficult child behaviors. Earlier, the students expressed aggression towards the child, and after the meeting they try to understand the specific behavior of their friend and include him/her in social life (...). I tried to change the image of a child among colleagues, who is now a "very important guest" for them, because he is the only student who has a terrarium at home and keeps reptiles", "During the weekly class meeting each student had to say what he/she is grateful for someone else from the class. Later, they had to write someone's positive character feature on a piece of paper"," PE tolerance and admiration for a handicapped person, a wheelchair ride for a healthy student"," Looking for good qualities in people around us". These answers demonstrate the extraordinary effectiveness of actions undertaken by individual teachers for the safety and security of all students. More than a half of the studied school graduates also did not notice regular initiatives aimed at developing empathy at school. An additional problem is the low level of developing selfesteem among students. Actions undertaken by school in that matter were assessed by a total number of $32 \%$ of the school graduates as 4 and 5. Developing self-esteem and shaping empathy are included in the scope of positive promotion/prevention for the benefit of creating an environment of safety and security. Another factor protecting against risks and threats includes social ties. Approximately, $50 \%$ of the school graduates observed school activities in the area of building ties between students, between teachers and students, and between students and the local community. The indicator of developing bonds with parents was slightly smaller, namely; only $30 \%$. The above answers show that teachers have little awareness about the essence of safety and security, preventive safety and security and safety participatory management at school. Making students involved in creating safety

Ewelina WŁODARCZYK (2019), Journal of e-Learning and Higher Education, DOI: $10.5171 / 2019.531037$ 
and security at school happens on a rare basis, even though a small percentage of teachers demonstrate an exceptional creativity in this area.

\section{Discussions}

The study concentrated on diagnosing the extent to which the assumptions of participatory management are taken into consideration in the preventive school activities. The obtained results made it possible to conclude that both teachers and headmasters unilaterally understand the importance of safety and security. These definitions presented in the literature by $\mathrm{R}$. Zięba, J.S. Nye or H.G. Brauch usually do not fit into the holistic approach to this issue. Without understanding this concept, it is not possible to design high quality preventive actions as far as safety and security are concerned.

Activities undertaken at schools are usually consistent with the defensive prevention which entails and concentrates on eliminating threats. These results are in line with the research conducted in previous years (Włodarczyk, 2017). The low effectiveness thereof was signaled i.a. by Z.B. Gaś and S. Śliwa. Taking the above into consideration, it might be concluded that the simplest and the most effective solutions, such as social integration or developing empathy are often skipped. Poland is not a member of the program entitled "Roots of empathy", which successfully implements the issue of preventing aggression and violence at school in Canada, New Zealand, the United States, the Republic of Ireland, England, Wales, Northern Ireland, Scotland, Germany, Switzerland, Netherlands and Costa Rica (Schonert-Reichl, 2012).

Students participate in the implementation of safety and security promotion to a limited extent. As it is emphasized by the researchers, less involvement (Rasmussen, 2006; Kumar, 2017) and the absence of coresponsibility (van Mierlo, 2005) translates into the effectiveness of actions (Hargreaves,
1991; Likert, 1967 za Shagholi, 2011) and motivation (Saha, S., 2015; Kumar, 2017). The low level of participation can also be demonstrated by the differences between teachers and students in assessing the effectiveness of preventive actions.

My research was focused on students' participation in the process of school safety management. The above studies should be further developed by introducing interviews with headmasters. Then, on their basis it can be stated which style of safety management is adopted at school. Parents should also participate in the process of safety participatory management. The scope of their involvement should also be subject to additional research.

\section{Conclusions and Recommendations}

Taking the above into consideration, it might be stated that the assumptions of participatory management are not sufficiently taken into account by teachers and headmasters in the concept of safety and security promotion. The greatest difficulty is related to the way of defining the concept of" safety and security", without which the nature of safety and security promotion and safety and security management cannot be understood. By identifying safety and security only with eliminating threats, one will focus on the system of bans, penalties, reprimands, the CCTV system and controlling. As research shows, this is how teachers define "safety and security" and suggest preventive measures and actions which are part of the authoritarian leadership style. What is more, due to the analysis of school preventive maintenance programs, it is possible to confirm that counteracting threats is treated as a priority in relation to providing constructive support for students coping with challenges. Providing incomplete definitions of those concepts in many cases, results from being not completely prepared for the profession at the university. Such deficiencies are compensated by those teachers by participating in conferences and trainings,

Ewelina WŁODARCZYK (2019), Journal of e-Learning and Higher Education, DOI: $10.5171 / 2019.531037$ 
and seeking information in the Internet. Moreover, teachers and headmasters do not include the need to eliminate risk factors and to strengthen factors protecting from threats while promoting safety and security. They concentrate, to a large extent, on risk factors which reduces the essence of safety and security promotion. Strengthening factors that protect from risks and threats, such as empathy, self-esteem or building relationships is not a common practice at school.

The scope of students' participation in activities aimed at safety and security promotion is also small. Teachers rarely talk to students about threats and risks, and do not allow them to evaluate school preventive maintenance programs. Preventive measures and actions suggested by teachers mainly take account of prescriptive strategies (control, monitoring and punishment), and the need to make students involved in safety and security management was noticed by only $1 \%$ of the teachers. The teachers, when asked about the scope of students' participation in preventive activities, indicated control during breaks, talks and the CCTV system. Slightly more than a half of the teachers declared that they make students engaged in constructing school preventive maintenance programs. As part of preventive activities at school, the school graduates mainly confirmed the use of the strategy regarding providing information about threats, conducting conversations with teachers and pedagogues, as well as a wide range of penalties, prohibitions and controls. Such actions do not fit into the assumptions of safety participatory management. The above-mentioned reasons may justify a lower assessment of the effectiveness of safety and security promotion implemented at school expressed by the students, compared to the evaluation formulated by the teachers.

On the basis of the conducted research, improving the quality of education regarding safety and security promotion during teacher training and expanding the offer of the intra- school teacher training system in this area might be recommended. Teachers and headmasters need to understand that effective safety and security promotion requires as well supporting human development, discovering students' skills, abilities, building their self-esteem, establishing bonds with the world, and understanding the situation of other people and their weaknesses.

One aspect that is often neglected in creating safety and security promotion schemes in Polish schools concerns long-term measures. Teachers and headmasters do not combine safety assurance with care for developing the factors that protect against risks, i.e. family bonds, empathy or self-esteem. Integration with the family and the local community occurs in the teachers' responses but actions concerning these issues are watered-down in the educational and preventive programmes or sporadic. This is just the substance of longterm safety assurance because the shortterm actions must include elimination of the risk factors. Another key issue is the methodology of the educational actions aimed at providing effective safety and security promotion. Such actions must not be boiled down to talks, discussions and lectures as it is usually the case. There is a need for actions involving emotions and practical activity. This is expected by the pupils and such proposals occur in conversations with them.

It is also important to perceive students as entities shaping their own safety and security who can and should participate in the safety and security management at school. The basis for implementing the assumptions of social participation is to make teachers and students aware that each of them pursue the same goals and everyone has the right to suggest their own solutions in matters regarding them. If we do not start to identify management with leadership, and teachers and directors do not want to delegate their own responsibility to students, it will be

Ewelina WŁODARCZYK (2019), Journal of e-Learning and Higher Education, DOI: $10.5171 / 2019.531037$ 
difficult to talk about effective safety and security promotion at school.

\section{References}

1. Brauch, H.G. (2011), Concepts of Security Threats, Challenges, Vulnerabilities and Risks, Coping with Global Environmental Change, Disasters and Security, Brauch, H.G., Spring, U.O., Mesjasz C., Grin, J., KameriMbote, P., Chourou B., Dunay P., Birkmann J. (ed.), Berlin Heidelberg: Springer-Verlag.

2. Cieślarczyk, M. (2011) Kultura bezpieczeństwa i obronności, Uniwersytet Przyrodniczo-Humianistyczny, Siedlce.

3. Clarke, R.D. (1982), 'Worker Participation in Health and Safety in Canada,' International Labour Reviev, 121 (2), 199206.

4. Clarke, S. and Ward, K. (2006), "The Role of Leader Influence Tactics and Safety Climate in Engaging Employees' Safety Participatio,' Risk Analysis. [Online], [Retrieved March 20, 2019], https://onlinelibrary.wiley.com/doi/abs/10. 1111/j.1539-6924.2006.00824.x.

5. Cotton, J.L., Vollrath, D.A., Froggatt, K.L., Lengnick-Hall, M.L. and Jennings, K.R. (1988), 'Employee Participation: Diverse Forms And Different Outcomes,' Academy of Management Review, 13 (1), 8-22.

6. Ćwik, B. (2017), 'A Survey on Willingness to Provide Warning Information within A Company during Crisis' Proceedings of the 2017 International Conference on Management Science and Management Innovation (MSMI), ISBN: 978-94-6252-3692, 23-25 June 2017, Suzhou, China, 170-174.

7. Ćwik, B. and Telep, J. (2005) Motywowanie jako podstawowy element zarządzania organizacją, Wyższa Szkoła Celna, Warszawa.

8. Ćwik, B. and Świerszcz, K. (2018), 'Conception of Warning Signals in
Organizational Monitoring Systems,' Proceedings of the 31th International Business Information Management Association Conference (IBIMA), ISBN: 9780-9998551-0-2, 25-26 April 2018, Milan, Italy, Innovation Management and Education Excellence through Vision 2020, Vol I -XI, 6151-6162.

9. Dachler, H.P. and Wilpert, B. (1978), "Conceptual Dimensions And Boundaries of Participation In Organizations: A Critical Evaluation,' Administrative Science Quarterly. [Online], [Retrieved March 20, 2019], https://www.jstor.org/stable/2392432.

10. Frei, D. (1977) Sicherheit: Grundfragen der Weltpolitik, Kohlhammer, Stuttgart.

11. Fromm, E. (2011) Ucieczka od wolności, Spółdzielnia Wydawnicza "Czytelnik", Warszawa.

12. Gaś, Z.B. (2006) Profilaktyka w szkole, Wydawnictwa Szkolne i Pedagogiczne, Warszawa.

13. Glendon, A.I. and Booth, R.T. (1982), 'Worker Participation in Occupational Health and Safety in Britain,' International Labour Reviev, 121 (4), 399-416.

14. Grenda, B., Ślachcinska, E. and Majdan, P. (2017), 'Terrorist Threats for the Critical Infrastructure of the State' Proceedings of the 4th International Conference on Management Science and Managenent Innovation (MSMI), ISBN: 978-94-6252-369-2, 23-25 June 2017, Suzhou, China, 165-169.

15. Gunningham, N. (2008), "Occupational Health and Safety, Worker Participation and the Mining Industry in a Changing World of Work,' Economic and Industrial Democracy. [Online], [Retrieved March 20, 2019], https://journals.sagepub.com/doi/10.1177/ 0143831 X08092460.

16. Hargreaves, D.H. and Hopkins, D. (1991) The empowered school: The management

Ewelina WŁODARCZYK (2019), Journal of e-Learning and Higher Education, DOI: $10.5171 / 2019.531037$ 
and practice of development planning, Cassell, London.

17. Hundeloh, H. and Hess, B. (2003) 'Promoting safety - a component in health promotion in primary and secondary schools,' International Journal of Injury Control and Safety Promotion, 10, 165-171.

18. Kim, S. (2002), "Participative Management and Job Satisfaction: Lessons for Management Leadership,' Public Administration Review. [Online], [Retrieved March 20, 2019], https://onlinelibrary.wiley.com/doi/abs/10. 1111/0033-3352.00173.

19. Korzeniowski, L.F. (2017) Podstawy nauk o bezpieczeństwie, Difin, Warszawa.

20. Kumar, S.P., Saha, S. (2017), "Influence of Trust and Participation in Decision Making on Employee Attitudes in Indian Public Sector Undertakings,' Sage Journals. [Online], [Retrieved March 20, 2019], https://journals.sagepub.com/doi/pdf/10.11 77/2158244017733030.

21. Likert, R. (1967) The human organization: Its management and value, McGraw-Hill, New York.

22. Locke, E.A. (1996), "Motivation through conscious goal setting,' Applied \& Preventive Psychology. [Online], [Retrieved March 20, 2019],

https://www.sciencedirect.com/science/arti cle/pii/S0962184996800059.

23. Locke, E.A. and Schweiger, D.M. (1979), Participation In Decision-Making: One More Look, Research In Organizational Behavior, Staw B.M. (ed.), JAI Press, Greenwich.

24. Luria, G. and Morag, I. (2012), "Safety management by walking around (SMBWA): A safety intervention program based on both peer and manager participation,' Accident Analysis \& Prevention. [Online], [Retrieved March 20, 2019], https://www.sciencedirect.com/science/arti cle/abs/pii/S0001457511001953.

25. Nielsen, K. and Randall, R. (2012), "The importance of employee participation and perceptions of changes in procedures in a teamworking intervention,' Work\&Stress. [Online], [Retrieved March 20, 2019], https://www.ncbi.nlm.nih.gov/pmc/articles /PMC3379743/.

26. Nowak, E. and Nowak, M. (2015) Zarys teorii bezpieczeństwa narodowego, Difin, Warszawa.

27. Nye, J.S. Jr (1989), 'Problemy badań nad bezpieczeństwem,' Sprawy Międzynarodowe, 6 (427), 51-64.

28. Parnell, J.A. and Crandall W. (2003), "Propensity for participative decisionmaking, job satisfaction, organizational commitment, organizational citizenship behaviour and intentions to leave among Egyptian managers,' The Multinational Business Review. [Online], [Retrieved March 20, 2019], https://www.questia.com/library/journal/1 P3-357479181/propensity-for-participativedecision-making-job.

29. Pieczywok, A. (2012) Edukacja dla bezpieczeństwa wobec zagrożeń i wyzwań współczesności, Akademia Obrony Narodowej, Warszawa.

30. Rasmussen, T.H. and Jeppesen, H.J. (2006), "Teamwork and associated psychological factors,' A review. Work \& Stress. [Online], [Retrieved March 20, 2019], https://www.tandfonline.com/doi/abs/10.1 080/02678370600920262.

31. Rest, K.M. (1996), “Worker Participation in Occupational Health Programs,' Sage Journals. [Online], [Retrieved March 20, 2019],

https://journals.sagepub.com/doi/pdf/10.11 77/216507999604400504.

Ewelina WŁODARCZYK (2019), Journal of e-Learning and Higher Education, DOI: $10.5171 / 2019.531037$ 
32. Santos, R. G., Chartier, M. J., Whalen, J. C., Chateau, D. and Boyd, L. (2011), "Effectiveness of school-based violence prevention for children and youth: Cluster randomized field trial of the Roots of Empathy program with replication and three-year follow-up,' Healthcare Quarterly. [Online], [Retrieved March 20, 2019], http://www.longwoods.com/articles/images /HQ_vol14_ChildHealth_Issue2_Santos.pdf.

33. Saran, J. (2011), Jakość kształcenia wyzwaniem dla edukacji na poziomie wyższym, $\mathrm{W}$ trosce o nauki pedagogiczne $\mathrm{i}$ rozwój polskiej edukacji, Szempruch J., Szymański M.J. (ed.), Innovatio Press.Wyd.Nauk.WSEiI, Lublin - Kraków.

34. Schonert-Reichl, K. A., Smith, V., Zaidman-Zait, A. and Hertzman, C. (2012), "Promoting children's prosocial behaviours in school: Impact of the "Roots of Empathy" program on the social and emotional competence of school-aged children,' School Mental Health. [Online], [Retrieved March 20, 2019],

http://cemh.lbpsb.qc.ca/professionals/Roots ofEmpathy.pdf.

35. Shagholi, R., Abdolmalki, R. and Moayedi, A.A. (2011), "New Approach in Participatory Management, Concepts and Applications,' Procedia Social and Behavioral Sciences. [Online], [Retrieved March 20, 2019], https://ac.els-

cdn.com/S1877042811002618/1-s2.0S1877042811002618-

main.pdf?_tid=11d3b1f7-98a3-4f51-a4acac6c7b5fdae7\&acdnat=1548856963_78f9dd ed9239ba234ec61fabc41e3ac4].

36. Soehod, K. (2008), "Workers' Participation in Safety and Health at Work,' Jurnal Kemanusiaan. [Online], [Retrieved March 20, 2019], https://jurnalkemanusiaan.utm.my/index.ph $\mathrm{p} /$ kemanusiaan/article/view/182.

37. Śliwa, S. (2015) Profilaktyka pedagogiczna, WSZiA, Opole.
38. Świerszcz, K. (2016), Integralne wychowanie na rzecz integralnego bezpieczeństwa - jako naglące wyzwanie współczesnych czasów, Obronność państwa. Uwarunkowania oraz organizacja bezpieczeństwa i obronności, Trejnis Z., Marciniak M. (ed.), Adam Marszałek, Toruń 2016.

39. Świerszcz, K. (2017), 'The Impact of Energy Poverty on the Level of Social Security' Proceedings of the 2017 International Conference on Management Science and Management Innovation (MSMI), ISBN: 978-94-6252-369-2, 23-25 June 2017, Suzhou, China, 175-178.

40. Świerszcz, K. (2019) Postrzeganie bezpieczeństwa energetycznego $\mathrm{w}$ kontekście przeciwdziałania ubóstwu energetycznemu społeczności lokalnej $\mathrm{z}$ wykorzystaniem zasobów geotermalnych na terenie Gminy Wiśniowa, WAT, Warszawa, (ISBN: 978-83-7938-217-0).

41. van Mierlo, H., Rutte, C., Kompier, M. and Dooreward, H. (2005), "Self-managing teamwork and psychological well-being: Review of a multilevel research domain,' Group \& Organization Management. [Online], [Retrieved March 20, 2019], https://journals.sagepub.com/doi/10.1177/ 1059601103257989.

42. Wagner, J.A. and Gooding, R. (1987), "Shared Influence And Organizational Behavior: A Meta-Analysis of Situational Variable S Expected To Moderate Participation-Outcome Re Lationships,' Academy Of Management Journal. [Online], [Retrieved March 20, 2019], https://www.jstor.org/stable/256012?seq= $1 /$ subjects.

43. Włodarczyk, E. (2017), 'Zarządzanie partycypacyjne bezpieczeństwem w szkole,' Annales Universitatis Paedagogicae Cracoviensis. Studia de Securitate et Educatione Civili, 7 (250), 277-295.

Ewelina WŁODARCZYK (2019), Journal of e-Learning and Higher Education, DOI: $10.5171 / 2019.531037$ 
44. Włodarczyk, E. (2018a), Zarządzanie partycypacyjne bezpieczeństwem, Vademecum bezpieczeństwa, Wasiuta, 0. ., Klepka, R., Kopeć, R. (ed.), Libron, Kraków.

45. Włodarczyk, E. (2018b), Profilaktyka bezpieczeństwa, bezpieczeństwa, Wasiuta, O., Klepka, R., Kopeć, R. (ed.), Libron, Kraków.

46. Zięba, R. (2012), '0 tożsamości nauk o bezpieczeństwie,' Zeszyty naukowe AON, 1(86), 7-11.

Ewelina WŁODARCZYK (2019), Journal of e-Learning and Higher Education, 